\title{
Control of Public Utilities in California*
}

I have been asked to address your Association on the control of public utilities in California. I would prefer to broaden the subject somewhat and give you a few thoughts on control of public utilities in general without specific application to this State. I do this because I desire to go more deeply into this subject than is perhaps expected because the impression is somewhat prevalent that regulation at the present time is being carried too far, and it is my belief that this impression is more prevalent among lawyers than any other class of people. This probably is because of the lawyer's intimate association with litigation, his quite constant attitude of an advocate and his consequent jealousy of any governmental expression which has even an apparent tendency to hamper free action. And it is further quite fitting that we discuss together the deep principles involved in public utility regulation because however we may feel about the propriety of such a condition, it is nevertheless a fact that the lawyers of this country up to the present time have most largely participated in its government, and, therefore, the opinions of the members of this Association will probably be quite largely reflected in legislation, executive action and court decision.

Mankind from the beginning, so far as we have any authentic account, has always existed in societies. Aristotle put the matter simply when he referred to man as a political animal. Philosophers may dispute about this, but the fact remains that whether society under government is a natural condition or one self imposed, historical man has always existed in communities and has always carried on his existence under some form of government. Organized governments have always existed and have differed from our present form of government only in degree. While man is primarily selfish, that is individual, yet we do not find him able in society always to in-

*An address delivered at the Fourth Annual meeting of the California Bar Association, November 20, 1913. 
dulge his selfish tendencies, and we have, not necessarily a conflict, but a compromise between the man as an individual and the man as a member of society, and this compromise establishes his status in society. Here again, however much philosophers may dispute, history and experience teach us that the natural inclination of a man is to prefer his own advantage. Every man, so far as I know, desires to a greater or less degree to have his own way. In recognizing this inclination I do not mean to be understood as suggesting that man does-not have natural social instincts, but I do believe that the pursuance of the selfish tendency in man is necessary to his existence as an individual. A further consideration of this question, however, would lead us into the discussion of certain philosophical conceptions which are not necessary for the purposes of this paper.

The function of government, in my opinion, should be to permit the utmost personal freedom which is possible to the individual consistent with his position as a member of society, and we believe that modern democracy is working out this idea; but we must realize all the while that the limit of democracy, and limit of independent personal action, is anarchy, for it will readily appear that if no check were put by society upon the indulging of selfish tendencies by individuals that we would have each individual a law unto himself. The intellectual anarchist urges that this is a desirable condition. As the other limit of government we have the purely paternal form which permits no freedom of action on the part of the citizen, and in which condition of society all things are directed by the state. That neither of these extremes is possible of existence for any appreciable time and that both defeat themselves, I believe will readily appear from a little reflection.

I hope then that we may be agreed that the most desirable form which society can take is represented under a government which recognizes the individualistic character of man, the self-seeking tendency which exists in all of us and likewise recognizes the social aspect of life, and recognizes the necessity of curbing the natural inclinations of men, but the necessity of curbing those natural inclinations only to the extent that is necessary to preserve the rights of others. I do not desire to be understood here, however, as advocating a laissez faire government wherein the affairs of the individual shall not be interfered with except it plainly appear that such 
interference is necessary in behalf of some other individual. There may very well be, and no doubt are cases where protection of the individual himself from himself may be necessary, but this disputed question need not here be further discussed because its determination one way or the other does not affect my conclusions in this paper. The fact that we have not found man living except in society and that at least at the present time all men live in some form of society does not prevent the individual in society from indulging his natural inclination to prefer his own advantage and to secure more of this world's goods than the welfare of his fellows should permit him to obtain. The natural acquisitive inclination of man exists in societies as a fact, and as a fact which must be recognized by society in dealing with social problems. Whether this acquisitive characteristic is to be permanent in individual men, and whether it is a permanent characteristic of which man cannot at any time be divested, are questions that are not necessary to be considered for the purpose of the discussion that we are now engaged upon. If it will be admitted by you that this natural inclination does now exist, then I will have established the starting point from which I desire to proceed to a discussion of the subject which I presume some of you are thinking has no relation to the matters considered up to this point, but which I believe will appear to be very intimately related as we proceed.

The principles of justice are immutable, but the conditions to which these principles must be applied continually change. We have undertaken to maintain a government in this country on the theory that all men are equal and entitled to certain privileges. What this means has been the subject of much controversy. It certainly does not mean that all men can run at exactly the same rate and that none can outstrip the others; neither does it mean that all men can calculate with the same degree of speed and accuracy. I presume it means, among other things, that men are equal before the law. But this statement, of course, means nothing if conditions exist in society which puts certain agencies in a position that though technically and legally they have no advantage before the law, yet through the operation of economic forces they do acquire such an advantage. In a race which was supposed to be a test of speed between two men we would not consider it a fair race and a fair test of speed if one of the men were allowed to assist himself over 
the course by some mechanical contrivance. Neither would we consider it a fair swimming race if two men swam in separate tanks of liquid, one of the consistency of water and the other of our down south molasses. But whatever these theories do mean it is perfectly apparent that there are certain things men must have in order to live, and that the right to the possession of these things is recognized as fundamental in our system of government. It is likewise apparent that in addition to the bare necessities of life there are certain other things which a man must have in order even to pursue happiness; for in passing it must not be forgotten that our fathers did not urge that every man has a right to be happy, merely that he has a right to pursue that elusive condition. But he certainly has a right to his life and to his liberty, and it is a principle of the common law carried into our government that the right to private property shall exist.

Such being the case, I lay it down as my first fundamental proposition that,

All men should have the right to the acquirement at least of the necessities on reasonable terms, and that no man shall be permitted to indulge his selfish inclination to get as much as he can for his commodity or his service in such a manner as to deprive his fellow of the opportunity to get the necessities of life on reasonable terms.

I lay down this simple fundamental proposition and limit it to those things necessary to existence merely so that there may be no possibility of disagreement with reference thereto. This principle has always been recognized by society and it should be a function of government to see to it that this necessary requirement be observed. The books are eloquent both of the selfish inclinations of men and the right of the government to curb such selfish inclinations and the long line of decisions firmly establishing the right of government to curb monopoly is testimony to the effect that men in the past have indulged their selfish tendencies and that the concert of opinion in all societies has been that when they attempt to indulge them to their neighbor's disadvantage the function of government is to restrain them.

Why is it that in certain fields of endeavor it has never been found necessary for government to intervene in behalf of the individual to protect such individual from the aggression of his 
neighbor? I think we will find it to be uniformly the case that where unrestricted competition has existed in any business or any industry the natural selfish inclinations of men have counterbalanced each other, and the selfish inclination of one man has served as a check against the selfish inclination of another and has made it unnecessary for government to intervene; but as economic forces become more complex and certain industries become bigger and stronger-as Theodore Roosevelt says, "when the butcher becomes the packer"-then such business may begin to occupy a position in the state which gives too full play to the selfish inclinations of men and gives no opportunity for the operation of counter-selfish tendencies and the government must be called upon to check the selfish tendency which is being carried too far for the good of the community. It is well to observe, however, that in no case should the restraint put upon any business be any greater than is necessary to readjust the relationship between the social need and individual selfishness. In one case very mild governmental interference may bring about the result and in another drastic measures must be resorted to. But in either event the interference of government is alike necessary, for when any agency has reached a position where those in charge thereof may indulge their selfish inclinations to the hurt of society, society, if it is awake, must and will intervene.

I lay down as my second fundamental proposition that,

Monopoly in some form is essential to constitute an agency a public utility.

I do not mean to be understood by this as saying that all monopolies are necessarily public utilities. But certainly in every public utility there is between it and at least a part of its patrons the relationship of a monopoly. It is necessary, however, to have in mind the distinction between what we call natural monopolies and what we may be permitted to call artificial monopolies. It is not possible for every shipper of goods or every person who desires to travel by railroad to have the option as to what railroad he shall utilize. Two railroads cannot come to the door of every home in this country. The same may be said of gas companies, lighting companies, telephone companies and the like. These agencies that from the very necessities of the case are to some of their patrons the only agency available for service, are what we mean by natural 
monopolies, and these, it is recognized by all students of monopolies, should be regnlated and not interdicted. The second class, which we have called artificial monopolies, is composed of those agencies which have grown up or been produced by the combination of smaller agencies or the elimination of smaller agencies that could operate in the field served by the monopoly in its final form. Concerning this second class of monopoly there has of late been a considerable difference of opinion as to whether regulation or elimination shall be its fate. One school of politics urges that the economies brought about by large combinations are of so great an advantage to the public, if such monopoly is properly regulated, that they counterbalance the loss of individual initiative and free business intercourse which is the result of the operation of the small concern. While the other school contends that unless the agency be a natural monopoly it should not be permitted to exist because it destroys opportunity and would ultimately produce a nation of hired men. I have only attempted to put very broadly the difference as I understand it, but of course this very interesting and most important question cannot be discussed in a paper of this character, and, as we are applying ourselves only to natural monopolies concerning whose status all thinkers are agreed, we may proceed to the consideration of our subject without controversy, I believe, on this point.

I would define a monopoly, as I use the term in this discussion, as an agency which has assumed a position in society where those in charge thereof may indulge their selfish tendencies to the hurt of society or to the detriment of the rights of the members of society as such. I know this is a definition in very broad and general terms, and in fact it is impossible to define many of the terms we use except thus generally, but this does not relieve us from the necessity of defining them and we may not, as Socrates has pointed out, define a thing by merely citing an example. But while the definition must of necessity be thus general, great difficulty does not exist when we come to the practical aspect of regulation because there we may know the effect of the agency in question and easily determine whether or not its effect is such upon its patrons and the rest of society as to require its regulation. To be sure the determination of this fact must be left to some authority, and 
it is no valid argument against regulation to say that the public authority, be it legislature, executive or court, may err in its determination of any question of fact. Such an objection merely amounts to a criticism of all government, and is the bare announcement that men even when acting officially make mistakes. But the determination of questions such as these must, as we have said, be left somewhere, and it is one of the weaknesses of human government that we must accept the mistakes of the final determining tribunal for the time being, resting secure in our belief that in the end justice will prevail.

It will readily appear from what has already been said that while general rules remain the same, and the general test should always be applied, yet particular agencies may with changing conditions become monopolies or utilities that theretofore were not, and this leads me to my third fundamental proposition which is that

Agencies become public utilities independent of a desire of the owners of such agencies and irrespective of any voluntary devotion of their property to public use.

This conclusion follows inevitably from our second proposition because if the conditions under which the agency acts determine its status and these conditions change from time to time a purely private business under one condition of society may become clothed with such an interest to the public under another condition of society that it becomes a public utility and subject to regulation. This point has been directly before the Supreme Court of the United States and was decided in accord with the position I here assume in the important and leading case of Munn v. Illinois, decided in 1876 and reported in the 94th United States at page 113. The position which is assumed by those public utility representatives at the present time who urge that some action on their part, which may be considered a dedication of their property to the public use, is necessary to subject their property to regulation, was there assumed by Mr. Justice Field in a strong and able dissenting opinion which is probably the clearest argument in favor of the other side of the question that is anywhere to be found. But the court has ever since followed the doctrine there announced and we find Justice Field applying it rigorously in subsequent cases. In commenting upon the contention of counsel in that case, the Supreme Court says in this connection: 
"Neither is it a matter of any moment that no precedent can be found for a statute precisely like this. It is conceded that the business is one of recent origin, that its growth has been rapid and that it is already of great importance. And it must also be conceded that it is a business in which the whole public has a direct and positive interest. It presents, therefore, a case for the application of a long known and well established principle in social science and this statute simply extends the law so as to meet this new development of commercial progress. There is no attempt to compel these owners to grant the public an interest in their property but to declare their obligations if they use it in this particular manner."

The facts in this case showed that the elevator owners in Chicago whose business was sought to be regulated by the statute in question, had entered into the business without any design to subject their property to a public use. Yet the court said the way they used their property and the circumstances surrounding the business determined the status and not what the owners of the property said about it. I am quite aware that decisions of state courts may be found, and that there is a recent decision of the Commerce Court of the United States likewise, which incline strongly to the doctrine that the design of the owners of the property is to be considered in determining whether or not the property may be subject to regulation. Yet the position of these courts is diametrically opposed to the position of the Supreme Court of the United States and is contrary to sound economics and to rational principles of government and by reason of these facts cannot stand as law. Action of the legislature, of the executive or of the court may for the time being determine a question contrary to sound economic principles, but such action cannot finally determine the matter, and while it may for a time have a retarding effect, yet in the end a people will devise some method of satisfying their needs. It may dam the flood of human progress but the pent up stream will break its bounds and sweep the obstruction aside and usually the channel is washed deeper when the stream resumes its flow. It might be urged that because one may dispose of or refuse to dispose of his property as he sees fit, that the one owning bread could not be forced to sell it, and under certain circumstances this position would be correct. 
But let some agency secure the entire supply of bread and then refuse under this rule to sell any of it, the people who desire the bread will get it even though the last resort of government be appealed to and force take the place of barter.

My fourth fundamental proposition is that,

Owners of public utility property hold such property by a different tenure than other owners.

This conclusion is fully as well justified and fully as well established in the decisions of the courts as any of those preceding it, yet it is the one concerning which there seems to be the greatest amount of confusion. Government has the inherent power to fix the rates of public utilities. This is one of the incidents of regulation and follows directly from the necessity which makes regulation justifiable. It is the power of the public utility to impose unfair burdens upon its patrons that justifies its control and justifies the state in depriving such utility of the power to determine at what price its commodity shall be sold. This is of the very essence of regulation. I imagine this is admitted by all, yet, notwithstanding this fact, we continually meet those who apparently cannot see that this condition makes it absolutely impossible to apply the same measure of value to a public utility property as to property not subject to regulation. There are primarily but two conceptions of value. The one most commonly accepted is power in exchange, and is more simply put as the price at which the thing will sell. The other conception is that value is represented by what it costs to produce a commodity. For the purpose of this discussion we will call the former of these "market value" and the second "investment."

For the purpose of public regulation market value can have absolutely no application. This position has been taken by the federal courts rather reluctantly at first but finally in the so-called Minnesota Rate Case the Supreme Court has at last gone definitely on record and has pointed out the impossibility of applying the ordinary conception of value to the public utility in a rate fixing inquiry. What the thing will sell for, of course, is largely determined in the market by its earning power. The earning power of a utility is determined by its rates. There you have the entire proposition, and we find ourselves immediately arguing in a circle, and I say that it is irrefutable that we must reject the market value 
theory as applied to public utility property when we are considering this property for the purpose of regulation. Regardless of the apparent simplicity of this proposition and the apparent absurdity of saying that market value shall apply to a public utility property, we still find it hard to dislodge the idea. Independent, however, of the logical inapplicability of the market value theory to public utility property for the purposes of regulation, there is a purely legal bar to such a position. The very power to regulate which is inherent in the government whenever any agency assumes a position which requires governmental compulsion to protect its patrons, places a cloud, we might say, upon the title to the property and prevents the property from being held by the same tenure as corresponding property devoted to private uses. This question of valuation is one of great importance and is worthy of an entire session of this Association, yet we will have to pass it with this short mention. It is my belief that a small amount of reflection on the part of any thoughtfil person would lead to the conclusion which is the basis of my fifth fundamental proposition, which is that

The amount of money wisely invested in a public utility property is the best evidence of value for rate fixing purpose and is the controlling element in determining the amount on which a utility should be permitted to earn.

I have already pointed out how market value can have no application to a utility property when regulation is involved. The Supreme Court of the United States in the so-called Minnesota rate case, recently decided, in addition to rejecting the market value theory, very lucidly pointed out many of the fallacies inherent in the so-called reproduction theory when carried to the extreme that public utility engineers and lawyers have advocated, and while that court does not there reject the reproduction theory of value in its entirety, it has considerably circumscribed it and has given it a place of much less importance than it has heretofore played in regulation matters. It is my belief that the reproduction theory of value of a public utility is important, and that what it would cost to reproduce the property in its present condition is an important element in determining what the investment of the utility owners is; but I believe the main function of appraisals 
is to reproduce conditions the evidence of which is now lacking, and that when the court says this is one of the elements to be considered it has in mind the fact that there should be some relationship between what it would cost to reproduce the property in its present condition and the money that has gone into the property. But still having in mind the cloud which is upon the public utility property we see that the unearned increment in adjacent land may not ordinarily be directly reflected in the right-of-way of the railroad. I know that this may at first hand appear to you to be a strong position to assume and probably difficult to maintain, but I say that neither from the standpoint of law nor equity is it necessary to accord to a utility owner the unearned increment in his land corresponding to the advance which has been made in lands adjacent to his property. In the case of a railroad for example, if the railroad were removed the value of both of the railroad's right-ofway and of the adjoining lands would be depressed. I know that this fact is urged by our railroad friends as justification for their increases in value. But let us analyze it a bit. It may well be that the section through which the railroad runs may become very valuable for residence purposes, for example, because of its natural situation and proximity to transportation, but can it be said that the land upon which the railroad is constructed is likewise enhanced in value for residence purposes? The very necessity of its being a railroad precludes the possibility of the land being used for residence purposes and therefore the particular land upon which the railroad is constructed cannot possibly be enhanced in value for residence purposes. The same may be said for agricultural, manufacturing, or any other purpose than that to which the property is devoted, and the very fact that the property must remain devoted to this purpose and may not, as may the adjoining property, be used for any other purpose which the owner may desire, puts a burden upon this property, and this burden can quite justly be placed in return for the large power of eminent domain which is conferred upon such an agency, and the conferring of such a power, if it were between private parties and within the power of one private party to grant to another, would be of sufficient consideration for the cloud which attaches to the property in the hand of the public utility owner. The burden is that this agency, in this 
instance, stay a railroad and thereby hold up the value of the other property; and the further burden is that this property cannot be used for purposes for which other property is utilized. It is valuable and has its entire value as a railroad.

Mr. Commissioner Thelen, of the California Commission, very ably pointed out in a paper recently presented to the National Association of Railway Commissioners ${ }^{1}$ the real relationship which exists between a public utility and the public, and that relationship is the relationship of principal and agent. I do not mean to be understood as saying that the bare legal relationship of principal and agent exists, but there is abundant authority to the effect that the condition is analogous to the strict legal relationship of principal and agent. A utility is engaged in a business in which the State could engage. This the Supreme Court of the United States has again and again pointed out. Any agency which occupies such a relationship to its consumers that it may legally be treated as a public utility is conducting a business which is of sufficient importance that the State, or a political subdivision thereof, might carry it on. But up to the present time the people of the various states of the Union, except in some cases in municipalities, have chosen to permit the doing of this work by private agencies with private capital, and have delegated these private agencies as their agents in the carrying on of what may be legally assumed as a governmental function. Such being the fact the public has a right to expect the business to be carried on at reasonable terms, and the public should not give any more reward to these private agencies carrying on this public business than is necessary to get the business done. The National Securities Commission appointed by President Taft in 1910, of which President Arthur T. Hadley of Yale was chairman, had this to say bearing upon this subject, with particular reference to railroads however:

"A reasonable return is one which under honest accounting and responsible management will attract the amount of investors' money needed for the development of our railroad facilities. More than this is an unnecessary burden; less than this, a check to railroad construction and to the development of traffic."

1 Published in 2 California Law Review, p. 3, (Nowember, 1913). 
With this sentiment I am entirely in accord. If public utility business is to be done by private capital the public should hold out only those inducements which are required to get the necessary amount of capital into the business. If it is required to hold out excessive inducements, then the doing of this business by private capital is too expensive and unless there are corresponding disadvantages which more than offset this expense then it certainly would be better for the State to do this business for itself, and the issue between private and public ownership of utilities will be fought out right here and the wise public utility manager who does not believe in public ownership should see to it that private enterprise performs the service as adequately and at as reasonable rates as public authority could hope to do.

The comparison then being between the result under public ownership and private ownership it may be well to see upon what the basis of earnings would be if public funds were put into the construction and operation of utilities. Certainly it requires no great amount of study to determine that if the public owns a utility the basis upon which the earning must be computed would be the amount of money which the public authority puts into it. In other words, if the public constructs a light plant and issues and sells bonds to get the money, the capital will be the money put in and interest will have to be earned on that else the undertaking is a failure. And from the standpoint of pure equity, what possible objection could a man with money to invest have to an arrangement whereby the amount of money which he invests shall be the basis upon which he shall earn? I do not think that ordinarily a public utility investor would object to putting his money into a public utility business under these circumstances if he was sure of a reasonable return upon the capital invested, and that on the faith of this assurance he would be willing to waive any expectation of increase in the value of the property due to unearned increment in lands. But the difficulty which confronts us is that we are required to attack the problem, as it were, in the middle and we find utilities in active operation and in full maturity at the time regulation becomes effective, and in every instance these utility owners advocate that basis of value which best fits the condition of the property they own. But I suggest to them, one and all, 
that the final determination of the issue between public and private ownership of these agencies will depend largely upon the attitude of the owners of public utilities on this and similar questions. Now I do not wish to be understood or quoted as saying, investment is the only element to be considered in determining the basis upon which a utility may earn. Nor do I say that the advance in value of adjoining lands may not be accompanied by advance in value of utility property by reason of increased business, or like causes which serve to fix the status of the utility as a successful and well conceived concern. But although increases in value of utility property and adjoining property may take place simultaneously yet they are nevertheless the result of entirely different and unrelated causes and one may happen and not the other. Nor finally do I say that any single element determines the basis upon which a utility should be permitted to earn. But I do confidently assert that considerations of fairness both to the utility and the public as well as sound principles of economics require that investment wisely and honestly made should be the most important and controlling element to be considered in arriving at the proper basis upon which a utility shall earn.

This brings me to my sixth fundamental proposition, which is that,

If we put a restriction upon public utility business and clouds upon public utility property, public authority has a reciprocal duty to protect these utilities and their property from injustice on the part of their patrons.

This merely means that the natural inclination to prefer one's own advantage is not confined to men who are engaged in public utility business. We are sometimes impressed with the fact that even rate-payers of public utilities are willing to indulge the same natural inclination. In other words, having denied a public utility the right to take all that can be forced from its consumers, to hold its property by the same tenure as other property is held and have its value determined by the same rule which determines value for privately owned property, we must see to it that those people who on the faith of the implied promise of the government that this changed relationship shall be compensated for in other directions, are not disappointed in this legitimate belief. I have already said that we should hold out just such inducements as are necessary to 
get sufficient money into public utility businesses to get the work done, but what I am pointing out here is that it is utterly unfair to hold out these inducements and after an investor, acting on the faith of the promise of the public, shall have put his money into these properties and thereby placed himself in a position of disadvantage from which he cannot retreat, thereafter to repudiate the promise and refuse to keep faith with the investor and to scale his earning down to the lowest amount which he may secure and keep his property afloat. Those of us who are engaged in public utility regulation and officially charged with the duty of administering the laws in this regard, have no difficulty in agreeing with the public utility representatives ordinarily as to operating expenses, or depreciation or matters of this sort, but when it comes to the question of the proper basis for earning, the proper value of the property, the investment upon which the utility shall be allowed to earn, we get into very serious controversies. No one engaged in public utility regulation who is at all fit for such a position of trust, questions the right of the utility to earn its operating expenses nor a proper amount for depreciation, nor an earning, in a wisely conceived utility upon the investment, but we do find it very difficult in many cases to agree with the utility representatives as to what is the proper basis upon which an earning shall be allowed.

The difficulty which here confronts us is the direct result of the method of financing which has existed on the part of public utilities in the past. The three important subjects to be considered in regulation of public utilities are rates, service and securities. Ever since the reign of William and Mary common carriers have been regulated as regards their rates, for as with all monopolies the first thing which confronted the public authority, and the first thing which was considered necessary to be regulated was the rates. In this State since 1879 we have had authority to regulate rates of railroad and transportation companies, and the cities have generally had authority to regulate the rates of some utilities operating in cities. But it has only been in comparatively recent years that it has begun to be seen that the really important thing is not the rate by itself but the reasonable rate for the adequate service. No one is benefited by a low rate for electricity if the voltage is so low that the electric 
light does not do him any good; neither is any one much interested in cheap rates on railroads if he is likely to be wrecked every time he travels, or if the roadbed is so rough that he becomes seasick. So with a better understanding of the whole subject it is seen that the question of service and rates must be considered together, and the question of the reasonableness of the rates always has reference to the character of the service. But even after this is realized it is found that there is still a third element which is now seen to be almost controlling upon this whole question, namely, the regulation of the fiscal affairs of these agencies performing the public service.

It has been urged that the financial condition of a utility is of no concern to governmental authority because its rates and service are determined independent of its financial condition. As $I$ attempted to point out in a recent paper before the National Association of Railway Commissioners, this contention is quite proper from a purely legal standpoint. Legally a utility is obligated to give adequate service at reasonable rates, but if it is crippled financially it finds it hard to do so. Utilities have been too largely financed in the past entirely from borrowed money. The usual practice has been to borrow practically all of the money which goes into the utility property through the sale of bonds, which necessarily must be sold at a discount, and to throw the stock in as a bonus, and the utility starts out bonded-that is mortgaged-beyond the cost of its property. This would seem off-hand a difficult procedure, but that it is not too difficult to be accomplished is evidenced by the fact that it has been the common practice of. utilities. You and I cannot go out and borrow all the money which will go into a house and then give a mortgage on the house as the sole security for such debt, yet this is just what has been done by a great many utility promoters. Necessarily, the bonds will not be paid at maturity and the stock will not be of value at all unless the value which goes behind these stocks and bonds and absorbs the water in thein comes out of the rates. I imagine it would be difficult to find a utility anywhere for which a portion of the capital has not been secured from the rates themselves. The tendency of the utility owner is to contend for a value of his property equal to the combined face value of his outstanding stocks and bonds 
and to insist upon an earning on this very often unreasonable amount, and it is when we meet this tendency that we find it hard to agree with the representatives of the public utilities. The par value of the outstanding stocks and bonds rarely has any relation to the investment in the property, and I lay it down as a proposition that cannot be gainsaid that the failure to pay dividends on stock is absolutely no evidence that the public is not sufficiently generous through rates. All utility students know this, yet few utility representatives are frank enough to admit it. The water-logged condition of utilities and not the high cost of living, not increases in wages, not additional cost of operation is the cause of most of the utilities' financial troubles in so far as such troubles are not common to all business enterprises. Utilities find it hard to borrow money because many of them have already borrowed too much. Unfortunately the good here must suffer with the bad, the sound financially are affected by the improper financial methods of others. Yet there is no way out of it that I can see other than a proper diagnosis of the disease, a proper understanding of the financial condition of the utility, and in those cases where it is found that too much security has been issued re-organizations will have to result. The controversy between public authority and public utilities is over the proper method of restoring the margin of safety between the debts of a utility and its assets. The utility contends it is hard to get money at present rates and therefore the rates should be raised. When these rates are raised money may be secured because, as it is urged, the earning power of the utility will justify the investment of more money in it. But this position is assumed in many instances without any knowledge, and apparently without any desire for knowledge, of what return on the investment the present rates are yielding. If a utility has an investment of twenty millions and has debts of forty millions-and this is not an over-drawn illustrationand it is required to pay $5 \%$ on these debts, it is required to earn $10 \%$ on its investment through the rates merely to pay the interest on its debts. Is a utility in this condition justified in urging that it be allowed to raise its rates so that it may borrow more money? The suggestion is ridiculous. In every such case in any wise approximating the condition here suggested, the utility should go into the 
hands of a receiver and let it be purchased by new owners at a price having a proper reference to the investment in the utility, and the present rates then may be seen to be very adequate and other people may be willing to put new money into this enterprise on exactly the same basis of earning as is now allowed.

Necessarily I have only given a sketchy outline of this tremendously important subject, a subject worthy of the most careful consideration by all of us. Utility representatives now say that they accept regulation, and we certainly give full faith to their statements, but some of them accept it because they must make a virtue of necessity, while I am free to admit that the more enlightened accept it because they see that it is the only condition under which the present method of public utility operation can continue. But one and all we find them indulging the natural inclination which is common to all of us, which we should not criticize but rather understand. They are not and should not be expected to be in this business from pure motives of philanthropy any more than you or I practice law from such motives. Gain has been, is now and always will be their main design and service of the public secondary. Besides no one likes to be curbed. If you or I were the master of a utility property we would not take kindly to what we considered outside interference. We would very much prefer to run our business as we should see fit, but that we should not be permitted to do so it has been my endeavor to point out in this paper. Regulation has come. It is now sought to be shown in many quarters that this regulation is responsible for the financial plight of the utilities in the United States. If a physician who discovers that a man is afflicted with a disease which the man knew nothing about is responsible for the disease, then public utility regulation is responsible for the financial plight of utilities. Regulation has merely served to discover the condition which has made investors heistate to put their money into utilities. To be sure, the condition of many of these utilities was known to some investors, for bond houses heretofore in too many instances having been speculators, have been willing to take securities because they assumed after all that securities were worth what they could get for them, and they have unloaded these securities onto the unsuspecting public, and if regulation had not stepped in rates would probably 
have reached a level which would have made these securities good. In other words, regulation in saying that rates shall only yield the cost of doing the business and a reasonable amount on the investment has prevented. an earning on water, and having prevented an earning on water, where water exists, financial confidence has been withheld from even those where water does not exist. The utility managers say to us that they cannot build extensions on air, that they must have money to extend their facilities; and we agree quite readily with this contention although there are those unkind enough to say that they have quite successfully built their properties in the past on water. But all we say to them is, restore your financial health. Only expect the public to pay you a return on what you have sacrificed, and if you are not willing to do this the public will have to do this business itself. And having taken this position, as I have just said, regulation has certainly not produced a position of financial ill health but has only developed the fact that it exsts. And I for one, shall always be willing to accord rates that will pay for doing the business which the utility has undertaken to do and in addition will give, not a miserable just-above-confiscation return on the investment, but a liberal and substantial fair play return in every instance after it shall be determined the basis upon which the return shall be allowed. This position, which is being assumed by the most thoughtful commissions in the country, may lead to temporary inconvenience of the public, but no more should it be condemned than a treatment for a disease which although it finally cures makes the patient a little sick while he is taking the medicine. The National Securities Commission, heretofore referred to, found this condition of financial ill health to exist, but it apparently was not willing to apply the remedy. The farmer who has a good farm finds no difficulty in borrowing money to improve the farm, and if he puts the additional money into the farm the combined value of the farm and the improvements bears a proper relationship to the debt. If those engaged in regulation are honest and will do what I have said they should do and what the California Commission is certainly trying to do, then before very long it will be easier to borrow money on utility property, if the enterprise is wisely conceived, than on any other kind of property. But it is useless to urge that for the sake of a 
temporary advantage we shall perpetuate an economic fallacy and permit the continuance of the financial practices of utilities, that have here been referred to, with the resulting permanent disadvantage.

In conclusion I desire again to impress upon you, members of the legal profession, the tremendous importance of this subject we have here been considering, and to ask you that you forget that you are advocates and remember that you are citizens of a great commonwealth, and remember that fair play and sound financial practices both on the part of the public and the public utility are absolutely necessary for the permanent welfare of the utility as well as the public. For my own part I wish to assure you that I am fully of the opinion that public authority should assume an attitude of helpfulness and co-operation and if it be determined that rates of the great railroad systems, for example, must be raised then let us raise them and apply the remedy for which our utility friends contend. But if on the other hand, after careful and impartial study, we find another remedy needed let us with equal firmness apply it even though it be less palatable to the patient. Our public utility work must be done and we must pay to have it done. But it must be done properly and on reasonable terms and I have sufficient optimism and sufficient belief in the genius of the American people to believe that what we need we will have the ability to get on proper terms.

San Francisco, California.

JOHN M. ESHLEMAN. 